\title{
LARYNGEAL CHONDROSARCOMA: SUCCESSFUL USE OF VIDEO LARYNGOSCOPE IN ANTICIPATED DIFFICULT AIRWAY MANAGEMENT
}

\author{
Vladimir Dolinaj, Sanja Milošev and Dušanka Janjević \\ Department of Anesthesiology, University Department of ENT, Clinical Centre of Vojvodina, Novi Sad, Serbia
}

\begin{abstract}
SUMMARY - Laryngeal chondrosarcoma is a rare mesenchymal tumor, most frequently affecting cricoid cartilage. The objective of this report is to present successful video laryngoscope usage in a patient with anticipated difficult airway who refused awake fiberoptic endotracheal intubation (AFOI). A 59-year-old male patient was admitted in our hospital due to difficulty breathing and swallowing. On clinical examination performed by ENT surgeon, preoperative endoscopic airway examination (PEAE) could not be performed properly due to the patient's uncooperativeness. Computed tomography revealed a spherical tumor that obstructed the subglottic area almost entirely. Due to the narrowed airway, the first choice for the anticipated difficult airway management was AFOI, which the patient refused. Consequently, we decided to perform endotracheal intubation with indirect laryngoscope using a C-MAC video laryngoscope (Karl Storz, Tuttlingen, Germany). Reinforced endotracheal tube $(6.0 \mathrm{~mm}$ internal diameter) was placed gently between the tumor mass and the posterior wall of the trachea in the first attempt. Confirmation of endotracheal intubation was done by capnography. In a patient with subglottic area chondrosarcoma refusing PEAE and AFOI, video laryngoscope is a particularly helpful device for difficult airway management when difficult airway is anticipated.
\end{abstract}

Key words: Chondrosarcoma - Surgery; Laryngeal Neoplasms - Surgery; Airway Management; Laryngoscopes; Videorecording; Case Reports

\section{Introduction}

Chondrosarcoma is a rare mesenchymal tumor accounting for approximately $0.1 \%$ of all head and neck malignancies ${ }^{1,2}$. The most common location of chondrosarcoma within the larynx is cricoid cartilage, thyroid and arytenoid cartilage ${ }^{3}$. The tumor most frequently occurs in the seventh decade, predominantly in male patients (male to female ratio $4: 1$ ). Slow growing and low tendency for metastatic spread is typical

Correspondence to: Vladimir Dolinaj, $M D$, Department of Anesthesiology, University Department of ENT, Clinical Centre of Vojvodina, Hajduk Veljkova 1, 21000 Novi Sad, Serbia E-mail: dovlamed@gmail.com

Received March 5, 2015, accepted September 14, 2015 for this tumor ${ }^{2,4}$. Symptoms depend on the size and location, and may include hoarseness, stridor and dyspnea ${ }^{5}$. Hoarseness is caused by narrowing of the glottis plane and compression of the inferior laryngeal nerves. Dysphagia is present due to extralaryngeal growth, originating in the posterior cricoids. Dyspnea and airway obstruction are caused by endolaryngeal and subglottic growth of the tumor ${ }^{6}$. The preferred treatment of the tumor is surgical procedure under general anesthesia ${ }^{7}$. Patients undergoing ENT surgical procedures with anticipated upper airway pathology often pose the greatest airway challenges to the anesthesiologist.

In this article, a case of laryngeal chondrosarcoma located in the subglottic area in a 59-year-old man is reported. 


\section{Case Report}

A 59-year-old man was admitted to our hospital due to difficulty breathing and swallowing. Concerning history, the patient claimed that he had noticed a small mass on his neck eight years before, which was slowly enlarging. Until October 2014, he had not complained of any clinical symptoms and signs. Clinical examination done by ENT surgeon revealed no pathological changes on the mucous membrane of the hypopharynx, epiglottis, ventricular fold and vocal fold, but a pathological change was palpated in the front side of the subglottic area in the projection of the thyroid gland. Additional computed tomography (CT) diagnostic of the neck was performed and disclosed a spherical tumor, $3.5 \mathrm{~cm}$ in diameter, which obstructed the subglottic area almost completely; the tumor mass was hypodense, well defined, at the level of the cricoid arch and first two tracheal rings.

Attending surgeon set the indication for surgical intervention under general anesthesia. Preoperative assessment and medical examination were performed by anesthesiologist in charge. According to medical history, the patient had coronary artery disease (CAD) and a stent was placed in October 2014. In addition, the patient was suffering from diabetes mellitus and hyperlipoproteinemia. The patient's actual body weight was $70 \mathrm{~kg}$, height $184 \mathrm{~cm}$ (body mass index 20.7). During physical examination of the lungs, inspiratory stridor was heard.

Bedside screening tests for predicting difficult intubation (Mallampati score, interincisor gap, upper lip bite test, maximal extension of cervical spine, and neck circumference) did not reveal difficult intubation. Due to the narrowed airway, difficult airway management was anticipated. Anesthetic plan of difficult airway management was made (by anesthesiologist in charge) according to the local protocol. The first choice for the management of the airway was awake fiberoptic intubation (AFOI) but communication with the patient was not good and he refused our proposal. Another option was endotracheal intubation using video laryngoscope. The patient was premedicated with midazolam $5 \mathrm{mg}$ and atropine $0.5 \mathrm{mg}$ i.m. General anesthesia was induced intravenously with propofol $2 \mathrm{mg} \mathrm{kg}^{-1}$, fentanyl $3 \mu \mathrm{g} \mathrm{kg}^{-1}$ and rocuronium $0.8 \mathrm{mg} \mathrm{kg}^{-1}$. Once the appropriate level of anesthesia

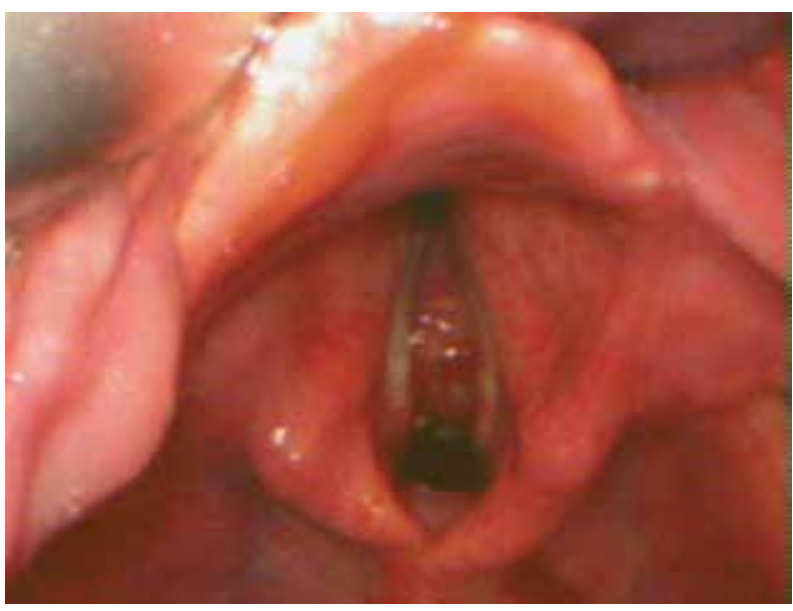

Fig. 1. Laryngeal view under video laryngoscopy.

and muscle relaxation was obtained, visualization of the larynx was performed by indirect laryngoscopy, with blade size 3, using a C-MAC video laryngoscope (C-MAC ${ }^{\oplus}$ Video Laryngoscope, Karl Storz, Tuttlingen, Germany).

Video laryngoscopy revealed the shape of a smooth surface, pale color tumor mass placed below the vocal cords. Also, the tumor filled most of the subglottic area and the airway was reduced (Fig. 1). Reinforced endotracheal tube $(6.0 \mathrm{~mm}$ internal diameter) was placed gently between the tumor mass and the posterior wall of the trachea in first attempt (Fig. 2). Confirmation of endotracheal intubation was done by capnography. Anesthesia was maintained with sevoflurane, oxygen in an oxygen/air mixture, fentanyl and rocuronium.

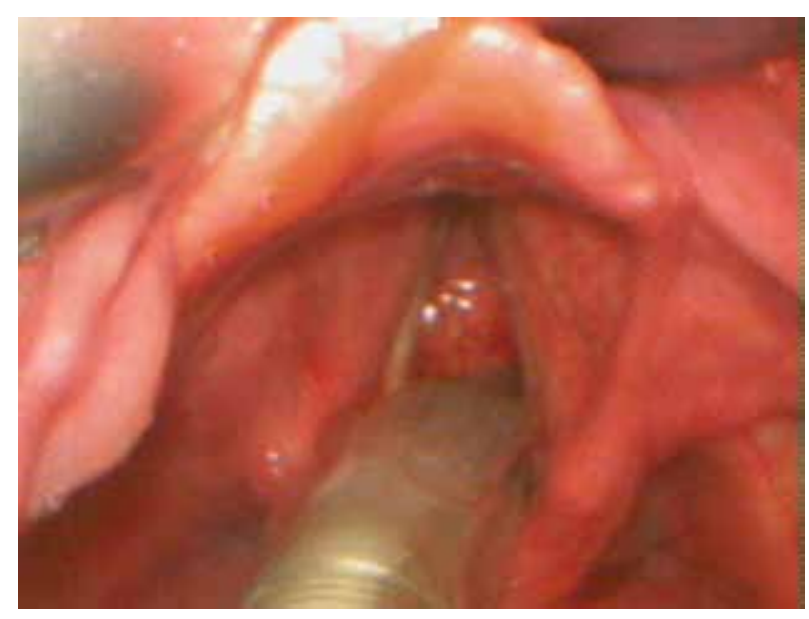

Fig. 2. Laryngeal view with reinforced endotracheal tube (6.0 ID). 
Resection of the tumor was performed. During surgical procedure, the diagnosis of chondrosarcoma was confirmed by intraoperative histologic examination (frozen section): Chondrosarcoma laryngis low-grade. After surgical procedure, the patient was awaked. He was breathing spontaneously and sufficiently. The patient was monitored in Recovery Room for one hour following the surgery, and then he was transferred to High Dependency Unit (HDU). The patient was discharged from the hospital on postoperative day 13.

\section{Discussion}

Laryngeal chondrosarcoma is a rare, slow-growing malignant tumor of the larynx ${ }^{1}$. Clinical symptoms and signs of the disease such as dyspnea, stridor, hoarseness or dysphagia may indicate the localization and size of the tumor, and may indicate the potential difficulties in airway management ${ }^{5,8}$. The diagnosis of subglottic tumor is based on physical examination, imaging such as $\mathrm{CT}$, and magnetic resonance imaging $(\mathrm{MRI})^{4}$. In our case, difficult breathing with inspiratory stridor was noted during physical examination suggesting difficult intubation/ventilation.

The predictors of difficult intubation were not revealed, but laryngeal lesion located in the subglottic area suggested difficult airway management. Anticipated difficult airway, due to localization of the pathological process, requires additional diagnostic investigation such as preoperative endoscopic airway examination (PEAE) performed by ENT surgeon.

The PEAE is performed to evaluate anatomical lesions of the upper airway that could not be assessed by standard airway examination. Current studies suggest that PEAE is helpful, especially when clinical signs of compromised airway are noted and when general anesthesia is required. On the other hand, PEAE would influence the plan of airway management. In a recent study, Rosenblatt et al. have suggested that preoperative endoscopic airway examination may affect the plan of airway management in $26 \%$ of studied patients 9 .

However, fiberoptic nasendoscopy has some limitations. First, the airway patency is protected by pharyngeal tone in awake patient, which will be reduced with the induction of anesthesia; therefore, normal nasendoscopy does not guarantee straightforward airway management once anesthesia is commenced ${ }^{8}$. Second, fiberoptic nasendoscopy requires cooperative and calm patient. In our case, cooperation between the patient and the ENT surgeon was not good and PEAE was not performed. Relying on our local guideline for airway management, AFOI was the first choice when we faced partial upper airway obstruction. According to our protocol, performing AFOI during elective surgery requires patient's written consent and full cooperation, which could not be obtained in the case presented.

The second choice for airway management was endotracheal intubation using video laryngoscope after general anesthesia induction. In our case, visualization of the glottis under video laryngoscope was excellent. We noticed that the tumor filled most of the subglottic part of the larynx and the airway was significantly reduced. Reinforced endotracheal tube was placed gently in first attempt. Indirect video laryngoscope allows close visualization of the larynx and provides full view of the glottis. However, this does not always guarantee easy intubation.

\section{Conclusion}

Preoperative endoscopic airway examination provides superior airway information which can influence further plan of airway management performed by anesthesiologist. In certain conditions, such as uncooperative patient with subglottic chondrosarcoma refusing AFOI, video laryngoscope is a particularly helpful device for anticipated difficult airway management.

\section{References}

1. Jackson RS, Leon ME, Mccaffrey TV. Chondrosarcoma of the subglottic larynx: submucosal microdissection with the operating microscope. Laryngoscope. 2013;123(5):1216-9. doi: 10.1002/lary.23957

2. Moerman M, Kreps B, Forsyth R. Laryngeal chondrosarcoma: an exceptional localisation of a not unfrequent bone tumor. Sarcoma. 2009;2009:394908. doi: 10.1155/2009/394908

3. Casiraghi O, Martinez-Madrigal F, Pineda-Daboin K, Mamelle G, Resta L, Luna MA. Chondroid tumors of the larynx: a clinicopathologic study of 19 cases, including two dedifferentiated chondrosarcomas. Ann Diagn Pathol. 2004;8(4):189-97. doi:10.1053/j.anndiagpath.2004.04.001

4. Ferlito A, Rinaldo A. The pathology and management of subglottic cancer. Eur Arch Otorhinolaryngol. 2000;257(3):168-73. 
5. Oliveira JF, Branquinho FA, Monteiro AR, Portugal ME, Guimarães AM. Laryngeal chondrosarcoma - ten years of experience. Braz J Otorhinolaryngol. 2014;80(4):354-8.

6. Buda I, Hod R, Feinmesser R, Shvero J. Chondrosarcoma of the larynx. Isr Med Assoc J. 2012;14(11):681-4. doi:10.1016/j. bjorl.2014.05.004

7. Dubal PM, Svider PF, Kanumuri VV, Patel AA, Baredes S, Eloy JA. Laryngeal chondrosarcoma: a population-based analysis. Laryngoscope. 2014;124(8):1877-81. doi: 10.1002/ lary. 24618

8. Crawley SM, Dalton AJ. Predicting the difficult airway. BJA Educ. 2015;15(5):253-7.

9. Rosenblatt W, Ianus AI, Sukhupragarn W, Fickenscher A, Sasaki C. Preoperative endoscopic airway examination (PEAE) provides superior airway information and may reduce the use of unnecessary awake intubation. Anesth Analg. 2011;112(3):602-7. doi: 10.1213/ANE.0b013e3181fdfc1c

Sažetak

\title{
LARINGEALNI HONDROSARKOM: USPJEŠNA PRIMJENA VIDEOLARINGOSKOPA U ZBRINJAVANJU OČEKIVANOG OTEŽANOG DIŠNOG PUTA
}

\author{
V. Dolinaj, S. Milošer i D. Janjević
}

Laringealni hondrosarkom je rijedak mezenhimni tumor koji najčešće zahvaća krikoidnu hrskavicu. Svrha ovoga rada je prikazati uspješnu primjenu videolaringoskopa u bolesnika s očekivanim otežanim dišnim putem koji odbija fiberoptičku endotrahealnu intubaciju na budno. Pedesetdevetogodišnji muškarac je primljen u našu bolnicu zbog otežanog disanja i gutanja. Zbog nesuradljivosti bolesnika otorinolaringolog nije uspio učiniti odgovarajući prijeoperacijski endoskopski pregled dišnog puta. Učinjena kompjutorska tomografija je pokazala sferičan tumor koji je skoro u potpunosti opstruirao subglotično područje. Zbog uskog dišnog puta prvi izbor za postupak s očekivanim otežanim dišnim putom je bila fiberoptička endotrahealna intubacija na budno koju je bolesnik odbio. Posljedično, odlučili smo izvesti endotrahealnu intubaciju indirektnom laringoskopijom pomoću videolaringoskopa C-MAC (Karl Storz, Tuttlingen, Njemačka). U prvom pokušaju je armirani endotrahealni tubus (unutarnji promjer 6,0 mm) nježno postavljen između tumorske mase i stražnjega zida traheje. Kapnografom je potvrđena endotrahealna intubacija. Zaključno, videolaringoskop je korisno pomagalo u održavanju otežanog dišnog puta u bolesnika s hondrosarkomom subglotičnog područja koji odbija fiberoptičku endotrahealnu intubaciju na budno, a u kojega se očekuje otežani dišni put.

Ključne riječi: Hondrosarkom - kirurgija; Laringealni tumori-kirurgija; Dišni put-zbrinjavanje; Laringoskopi; Video snimanje; Prikazi slučaja 